\title{
Correction to: Learning class-specific word embeddings
}

\author{
Sicong Kuang ${ }^{1} \odot \cdot$ Brian D. Davison ${ }^{1}$
}

Published online: 18 November 2019

๑) Springer Science+Business Media, LLC, part of Springer Nature 2019

\section{Correction to: The Journal of Supercomputing (2019) https://doi.org/10.1007/s11227-019-03024-z}

The article Learning class-specific word embeddings, written by Sicong Kuang and Brian D. Davison, was originally published electronically on the publisher's Internet portal (currently SpringerLink) on 23 October 2019 with open access. With the author(s)' decision to step back from Open Choice, the copyright of the article changed on 18 November 2019 to (C) Springer Science+Business Media, LLC, part of Springer Nature 2019 and the article is forthwith distributed under the terms of copyright. The original article has been corrected.

Publisher's Note Springer Nature remains neutral with regard to jurisdictional claims in published maps and institutional affiliations.

The original article can be found online at https://doi.org/10.1007/s11227-019-03024-z.

Sicong Kuang

sik211@cse.lehigh.edu

Brian D. Davison

davison@cse.lehigh.edu

1 Lehigh University, Bethlehem, PA, USA 